ing from phytochrome conversion is transmitted in the opposite direction. Further results suggest that this must be movement of a chemical message, and not merely transmission of the light stimulus or of phytochrome molecules. Nodulation is reduced in the roots of plants of which the shoots alone have been treated with far-red light. Irradiation of the roots with red light, however, could not relieve the inhibition.

It is not simple to picture the part that phytochrome plays in the development of root nodules, but it does seem that the presence of Pfr is necessary for nodulation. Plants grown in total darkness show little or no tendency to form nodules, although this can be partially overcome by low temperatures or exposure to small amounts of red light (McGonagle, Proc. Roy. Soc. Edinburgh, B, 63, 219; 1949). This is probably a result of carbohydrate availability. It is clear that it is the symbiotic union of plant and bacterium which is affected by the phytochrome system, and not merely the physiological state of the plant alone. Lie has found that far-red light most effectively inhibits nodulation when the shoots or roots are irradiated about three days after infection: far-red light given at other times was comparatively ineffective. It will be immensely interesting to learn more of how phytochrome can influence such a complex interrelationship; perhaps this will prove a new approach to tackling the fascinating problems in the physiology of symbiosis.

\title{
Immunization against Rubella
}

by

\section{J. A. DUDGEON}

Department of Neurobiology, The Hospital for Sick Children, Great Ormond Street,

London $\mathrm{WCl}$
Although rubella (German measles) causes comparatively few congenital malformations, these are often severe and frequently multiple. Techniques are now available for accurate diagnosis and the development of a vaccine; in the future it should be possible to prevent rubella during pregnancy. Although vaccines seem to be attenuated, their effect on the foetus is not known, and they should not be given during pregnancy. Immunization schedules must be devised with this in mind.
IN the past nine months two international conferenees have been held to discuss immunization against rubella. The first took place in London in November 1968 under the auspices of the Permanent Section of Microbiologieal Standardisation ${ }^{1}$ and the second in February this year st the National Institutes of Health, Bethesda, Maryland. ('The proceedings of this were due for publication in July and August ${ }^{2,3}$.) Both conferences were concerned primarily with immunization, but at both the opportunity was taken to take a broad look at rubella as a disease. There were papers on the epidemiology and natural history of rubella $a^{1,2}$, clinical aspects and pathogenesis ${ }^{2}$, methods of isolating the virus and identification of rubella antigens and antibody ${ }^{1,2}$. 'There was also detailed discussion on congenital rubella, its clinical aspects, pathogenesis and immunology $y^{1,2}$. For those not intimately concerned with the study of this virus disease, the holding of an international confere nce, let alone two, may at first sight seem rather strange.

To most people, rubella is a mild disease with few complications, which most of us contract at some time in childhood or adolescence. Frequently pcople cannot remember if they have had rubella or not (unlike moasles) and, if they think they have, they are often wrong. Other infections can simulate rubella and subclinical infection is common; the net result being that accurate diagnosis on clinical grounds is difficult even in the presence of an epidemic. Why then should this disease attract so much attention at this time? For the answer one must go back thirty years.

\section{Rubella in Pregnancy}

In 1938 Hiro and Tasaka transmitted rubella to children by the inoculation of blood and bacteria-free filtrates of naso-pharyngeal washings taken during the prodromal phase of the disease; only a proportion of the children inoculated developed clinical rubella. This confirmed the concept, put forward by Hess in 1914, that rubella was a virus disease. The significance of this discovery was overshadowed by the outbreak of the Second World War and the inevitable disruption of scientific research. But a year or so later an cvent occurred which was radically to change opinion concerning the role of rubella virus as a pathogen. In 1940, rubella appeared in epidemic form in Australia. The cpidemic was extensive and the discase scvere. Many young men and women called up for military service contracted it and for a time, because of its severity, the diagnosis of rubella was in doubt. 'The following ycar, in the first half of 1941, the late Sir Norman Gregg ${ }^{5}$, an ophthalmologist in Sydney, observed an unusual number of cases of congenital cataract. In addition to cataracts, most of which were bilateral, many infants were small, illnourished and difficult to feed. In sixty-seven of tho seventy-eight pationts, Gregg ${ }^{5}$ found a history of rubellat in the mother in early pregnancy and forty-four cases also had congenital heart disease. He established this association on clinical and epidemiological grounds. Later Swan et al.$^{6}$ in Adelaide and Gregg ${ }^{7}$ found that a high proportion of the children, as they became older, were deaf. The syndrome of cataracts, heart disease and deafness often associated with mental retardation came to be known as the "rubella syndrome". By 1948 confirmatory reports of the association betwoen maternal rubella in carly pregnancy had come from all over the world. This was the first evidenco of an intrauterine infection leading to congenital malformations.

At first the risk of rubella in pregnancy seemed to be very great; nearly 100 per cent of infection occurrcd in the carly wecks of pregnancy, but this can now be explained 
by the fact that the information about the mothers' illnesses in pregnancy was sought many months, even years, afterwards. Later, prospective studies carried out in Sweden ${ }^{8}$ and Great Britain ${ }^{9}$ revealed lower figures of 10 to 15 per cent for congenital malformations following first trimester rubella. Nevertheless, these prospective studies probably underestimated the risk as much as the retrospective studies overestimated it. Methods of assessment varied and only malformations of the rubella syndrome type were looked for following a maternal illness with a rash diagnosed on clinical grounds. A precise figure for the risk of foetal damage cannot bo obtained, but it is clearly much higher in the first 8 weeks of pregnancy than in the second 8 weeks. If the risk of foetal death, stillbirths and defects recognized later in childhood is added to the principal risk of congenita. malformations, the overall risk during the first 16 weeks of pregnancy is in the region of 30 per cent. Altogether this constitutes a serious risk, but it has to be remembered that even after maternal rubella at the most critical stago for the foetus, the infant may be normal at birth and remain normal ${ }^{10}$.

\section{Culture of Rubella Virus}

In 1962, 21 years after Gregg's discovery, Weller and Neva ${ }^{11}$ and Parkman, Buescher and Artenstein ${ }^{12}$ reported simultaneously the isolation of rubella virus in tissue culture. This led to a major breakthrough in rubella virus research. It was soon shown by Weller ${ }^{13}$ and later by MeCarthy and Taylor-Robinson ${ }^{14}$ that rubella virus could be cultured in many different types of cell culture. These new techniques led to the development of diagnostic procedures for rubella based on virus isolation and antibody determination by neutralization and complement fixation techniques. The subsequent discovery by Stewart et al. ${ }^{15}$ of a virus haemagglutinin led to the development of the more simple haemagglutinin-inhibition test. This technique has revolutionized the study of many different aspects of rubella-diagnosis, epidemiology and pathogenesis. Although the test is comparatively simple to perform, there are several technical difficulties associated with it, for example non-specific agglutination at the removal of non-specific inhibitors. Experience is required in the interpretation of the tests.

The extensive rubella epidemics of 1962-65 resulted in the birth of many malformed children, but the development of diagnostic techniques immediately before this led to the accumulation of much new knowledge concerning congenital rubella. New clinical manifestations were recognized in addition to those of the classical rubella syndrome and it became clear that intrauterine infection could lead to a wide spectrum of clinical manifestations, ranging from a disseminated infection with multi-organ involvement to subclinical infection ${ }^{16-18}$. In the latter type of case resulting from disseminated foetal infection there is usually a low birth weight, neonatal purpura. with thrombocytopenia and enlarged liver and splecn. These children often have cataracts and heart disease, and as they grow older are found to be deaf and retarded. Virological studies have revealed that intrautcrine infection leads to a chronic infection of the foetus which may persist for ecveral months aftcr birth ${ }^{19,20}$, and in some organs such as the lens for many years. Contrary to expcctation, infents with congenital rubella were found to have high levels of rubella antibody which also persisted when maternally transmitted antibody should havo disappear $\mathrm{d}^{21-23}$. At birth, rubella antibody is contained chiefly in the IgM frection ${ }^{24}$ and high levels of IgM ere often found in the blood ${ }^{25}$. Persistence of rubella virus and antibody and increased levels of IgM have made possible a retrospective diagnosis of intrauterine rubella after birth.

Techniques were developed for isolating rubella virus from foetal tissues and in organ cultures ${ }^{26,27}$, revealing new information about the pathogenesis of congenital rubella and about possible mechanisms by which the virus damages cells ${ }^{28,29}$. New techniques have been developed to study rubella antigen. In addition to infectious virus, a haemagglutinin and two complement fixing antigens have been described ${ }^{30}$ and Le Bouvie $\mathrm{r}^{31}$ recently indiceted that there may be others. Rubella is an RNA virus consisting of a roughly spherical particle, approximately $700 \AA$ in diameter, but with no obvious symmetry. According to Almeida ${ }^{32}$ it has some biological features in common with arboviruses but should not at present be classified as one of that group.

\section{Live Vaccine}

Until a few years ago the only method of prophylaxis against rubella was with immune globulin. Although on clinical grounds there seemed to be some protection, it is now clear from virological studies that protection with a standard dose of 750 to $1,500 \mathrm{mg}$ of pooled globulin cannot be guaranteed. Schiff ${ }^{33}$, however, has shown that infection can be prevented if immune globulin of high titre

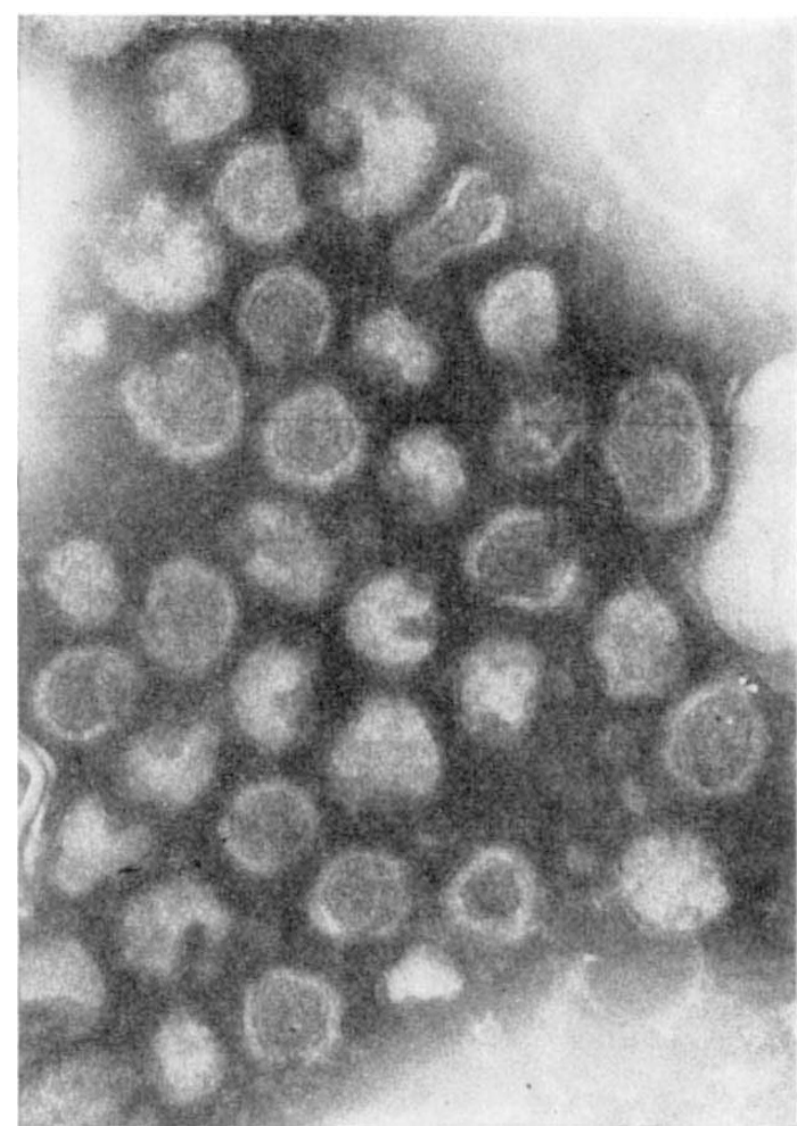

Fig. 1. Partieles of rubella virus $(\times 180,000)$, which have bren aggregated by a specific antibody. 
is administered immediately after contact. Of greater practical importance, however, is the development of a live attenuated vaccine. In 1966 Parkman and Meyer and their colleagues ${ }^{34}$ reported that a strain of rubella virus had been attenuated by serial passage in African green monkey kidncy cells and was immunogenic in children. This gave great impetus to vaccine development and in particular to the search for a vaccine which could be prepared in a cell substrate other than monkey kidney tissue because of the risk of extraneous agents. Several vaccines have now been developed and have already undergone extensive clinical trials ${ }^{1,3}$. Among these are vaccines prepared in primary rabbit kidney tissue (Cendehill strain ${ }^{36}$ ); in duck embryo cultures (HPV-77DE5 and Benoit strains) ${ }^{37}$ and in human diploid fibroblast cells (RA27/3 strain) ${ }^{38}$. These vaccines have several points in common. They produce very fow reactions in susceptible children; they produce seroconversion in almost 100 per cent of vaccinees and all lead to excretion of the vaccine virus in the nasopharynx for a variable period during the second or third week after vaccination. Transmission of infection, however, has not been reported ${ }^{2,3}$. Reactions in adults, however, are more noticeable ${ }^{39}$ but, with the exceptions of joint pains and arthritis, observed with some vaccines, particularly in adult females ${ }^{1-3}$ reactions have been generally mild.

Vaccine development has now reached the stage when protection can be offered to the community. Already one vaccine, the Cendehill, has been licensed in Switzerland

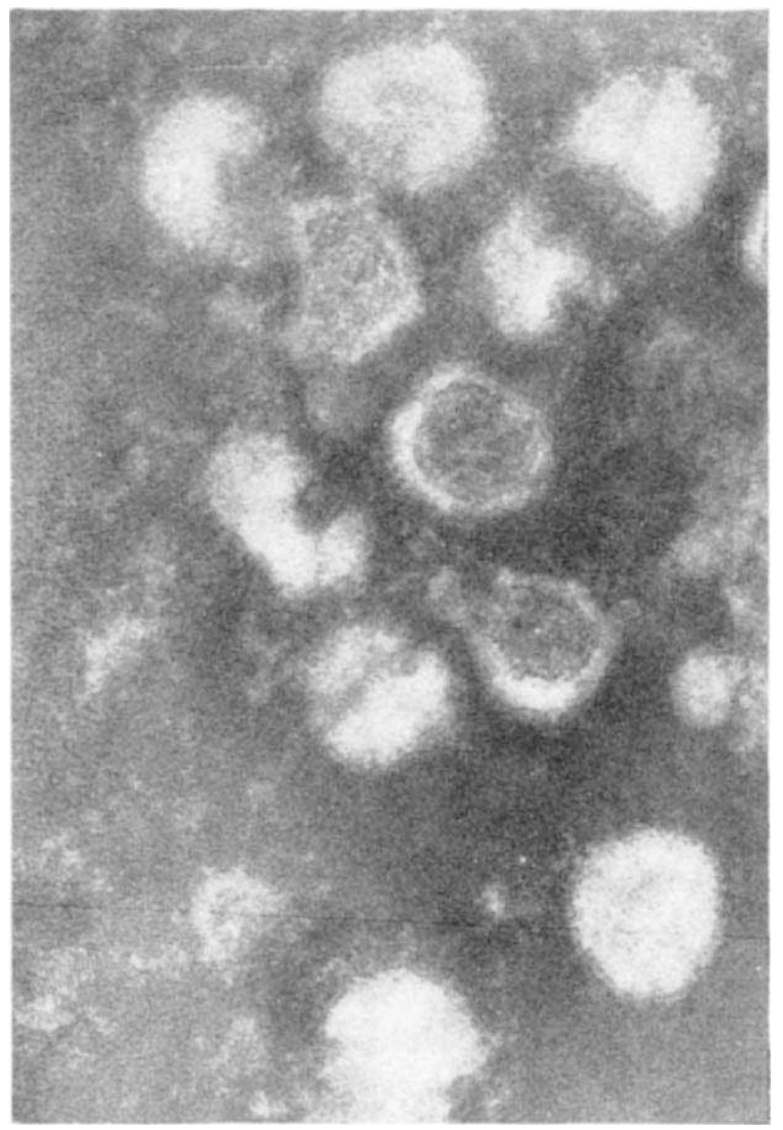
Fig. 2. Particles of rubella vrus $(\times 250,000)$; there is a clear lack of
any distinctive structure. The small fringe surrounding the particles is clearest in the particle in the top left hand corner. and Belgium and a pre-license statement from the United States indicates that vaccine may soon be licensed there ${ }^{40}$. How should rubella vaccinc be used and at what age? Approximately 15 per cent of individuals reach adult life without having had rubella, but this number varies greatly from one country to another. Until more is known about the lengih of immunity following rubella vaccines it would be premature to make a firm decision on the optimal age at which immunization should be introduced. There are two possibilities. First, immunization in infants and young children may be introduced with the ultimate object of eradicating the disease; second, the alternative approach may be used of immunizing older children, particularly girls before puberty. Although there may be differences of opinion on the age for immunization, all are agreed that rubella vaccines should not be given to anyone who is pregnant or in whom pregnancy is a possibility. The effect of vaccine virus strains on the human foetus is not known, and there is no method of measuring pathogenicity for the foetus. For this reason vaccine, although attenuated, should be regarded as potentially dangerous for the foctus.

${ }^{1}$ Proc. Intern. Symp. Rubella Vaccines, London, 1968, Symp. Series Immuno biol Standard, il (Karger, Basel, New York, 1968).

2 Amer. J. Dis. Childhood (in the press).

${ }^{3}$ Amer. J. Dis. Childhood (in the press).

+ Hiro, Y., and Tasaka, S., Mschr. Kinderheilk, 76, 328 (1938).

${ }^{5}$ Gregg, N. McA., Trans. Ophthalmol. Soc. Austral., 3, 35 (1941).

${ }^{6}$ Swan, C., Tostevin, A. L., Moore, B., Mayo, H., and Black, G. H. B. Med. J. Austral., 2, 201 (1943).

'Gregg, N. McA., Trans. Ophthalmol. Soc. A ustral., 4, 119 (1944).

${ }^{8}$ Lundström, R., Acta Paediat., Suppl. 133 (1962).

- Manson, M. M., Logan, W. P. D., and Loy, R. M., Rep. Publ. Hlth. Med. Subj., 101 (1960).

${ }^{10}$ Dudgeon, J. A., Arch. Dis, Childhood, 42, 110 (1967).

${ }^{11}$ Weller, T. H., and Neva, F. A., Proc. Soc. Exp. Biol. and Med., 111, 215 (1962).

12 Parkman, P. D., Buescher, E. L., and Artenstein, M. S., Proc. Soc. Exp. Biol. and Med., 111, 225 (1962).

${ }^{13}$ Weller, T. H., and Neva, F. A., Arch. Virusforsch., 17, 393 (1965).

14 MeCarthy, K., and Taylor-Robinson, C. H., Brit. Med. Bull., 23, 185 (1967).

is Stewart, G. L., Parkman, P. D., Hopps, H. E., Douglas, R. D., Hamilton, J. P., and Meyer, H. M., New Engl. J. Med., 275 (1966)

${ }^{16}$ Proc. Rubella Symp. Amer. J. Dis. Child., 110 (1965).

17 Schiff, G. M., Amer. J. Dis. Childhood, 110, 441 (1965).

${ }^{8}$ Butler, N. R., Brit. Med. J., 2, 1027 (1965).

${ }^{29}$ Alford, jun., C. A., Neva, F. A., and Weller, T. H., New Engl. J. Med., 271, 1275 (1964).

20 Cooper, L. Z., and Krugman, S., Arch. Ophthalmol., ry, 434 (1967)

${ }_{21}$ Plotkin, S. A., Dudgeon, J. A., and Ramsay, A. M., Brit. Med. J., 2, 1296 (1963).

${ }^{22}$ Weller, T. H., Alford, jun., C. A., and Neva, F. A., New Engl. J. Med., 270, 1039 (1964).

${ }^{23}$ Dudgeon, J. A., Butler, N. R., and Plotkin, S. A., Brit. Med. J., \&, 155 (1964).

${ }^{24}$ Alford, jun., C. A., Amer. J. Dis. Childhood, 110, 455 (1965).

${ }^{25}$ Soothil, J. F., Lancet, i, 1385 (1966).

${ }^{26}$ Banatvala, J. F., Best, J. M., and Kistler, G. S., Proc. Intern. Symp. Rubella Vaccines, London, 1968, Symp. Series Immunobiol. Standard, 11, 161 (Karger, Basel/New York, 1969).

${ }_{27}$ Rawls, W. E., J. Amer. Med. Assoc., 203, 627 (1968).

${ }_{28}$ Rawls, W. E., in Progress in Medical Virology, No. 10 (Karger, Basel, 1968).

${ }^{29}$ Dudgeon, J. A., Amer. J. Dis. Childhood (in the press).

${ }^{30}$ Lennette, E. H., and Schmidt, N. J., Amer. J. Dis. Childhood (in the press).

${ }^{31}$ Le Bouvier, G. L., Proc. Intern. Symp. Rubella Vaccines, London, 1968, Symp. Series Immunobiol. Standard., 11, 133 (Karger, Basle/New York,

${ }^{32}$ Almeida, J. D., Amer. J. Dis. Childhood (in the press),

${ }^{33}$ Schiff, G. M., Proc. Intern. Symp. Rubella Vaccines, London, 1968, Symp. Series Immunobiol. Standard, 11, 83 (Karger, Rasel/New York, 1969); Amer. J. Dis. Childhood (in the press).

${ }_{34}$ Meyer, H. M., New Engl. J. Med., 275, 575 (1966).

35 Parkman, P. D., Meyer, H. M., Kirschstein, R. L., and Hopps, H. E., New Engl. J. Med., 275, 569 (1966).

${ }^{3 \theta}$ Huygelen, C., and Peetermans, J., Arch. Virusforsch., 21, 357 (1967).

${ }^{37}$ Hilleman, M. R., Clin. Pharmacol. Ther, , 7, 752 (1966).

${ }^{3}$ Plotkin, S. A., Amer. J, Epidemiol, 86, 468,1967$)$

${ }^{39}$ Dudgeon, J. A., Brit. Med. J., 1, 271 (1969).

4 Mortality and Morbidity Weekly Rep. No. 12 (Communicable Disease Center, Atlanta, Georgia, 1969). 